\title{
ISOLATION AND CHARACTERIZATION OF BACTERIOCINOGENIC LACTIC ACID BACTERIA FROM INDIGINOUS DAIRY SOURCE AND ITS ANTIMICROBIAL POTENTIAL
}

\author{
Azam Shakeel, ${ }^{1, *}$, Muhammad Saeed ${ }^{1}$, Muhammad Atif Randhawa'and Muhammad Anjum Zia ${ }^{2}$ \\ ${ }^{1}$ Fcaulty of Food, Nutrition and Home Sciences, University of Agriculture, Faisalabad-38040, Pakistan; ${ }^{2}$ Department \\ of Biochemistry, Faculty of Sciences, University of Agriculture, Faisalabad-38040, Pakistan. \\ "Corresponding author's e-mail: azam1087@gmail.com
}

\begin{abstract}
The aim of this research was to isolate lactic acid bacterial (LAB) strains, characterize them and classify the bacteriocin producing $\mathrm{LAB}$ strain from indigenous dairy sources. Antimicrobial potential of LAB strain was tested against $L$. monocytogens. The antimicrobial compound was also tested for maintaining the decreased colony forming unit (CFU) for minimally processed vegetables like carrots, cabbage and lettuce in second phase of the research. The initial identification was based on conventional morphological and biochemical analysis while the final confirmation was done by utilizing advanced molecular tools. Prior to all these manipulations the growth conditions were carefully optimized for the respective strains. The study finally led us to conclude that Lactococcus lactis subsp. lactis was the most abundant type of lactic acid bacteria found in indigenous dairy products (sour cream and cheese) samples studied. A bacteriocin (Lacticin SC07) produced during the growth of Lactococcus lactis subsp. lactis was purified partially by using biochemical technique ammonium sulfate precipitation in different percentages (60\% and 80\%). These precipitations lead to a 437 -fold increase in total lacticin SC07 activity. SDS-PAGE electrophoretic pattern of lacticin showed that it is a single peptide band of $1.7 \mathrm{kDa}$. But, $3.7 \mathrm{kDa}$ dimers also showing lacticin SC07 activity. The findings of my research revealed that the isolated LAB strain has good potential for bacteriocin production and antimicrobial potential that exerts in the usage of this bacteriocin (lacticinSC07) as a natural preservative in minimally processed vegetable industry.

Keywords: Bacteriocin, antimicrobial potential, indigenous dairy sources, purification, electrophoretic pattern, natural preservative.
\end{abstract}

\section{INTRODUCTION}

Food-borne infections are globally midst the utmost critical and inflated public health issues, as a main cause of morbidity. The reported numbers of food-borne diseases and intoxications still increased over the past decade because all the food safety techniques and food handling processes cannot overcome the risks relevant to food spoilage and food pathogens. Campylobacter, Salmonella, Listeria and viruses caused the most common food-borne infections in the European Union and affect more than 380,000 citizens per year (EFSA, 2009). Fresh-cut lettuce from more than a decade has been one of the major concerned raw material which accounts for $80 \%$ of the total production of fresh cut. The salad bars now became popular and demand of freshly cut lettuce also increased, hence available in convenience stores, supermarkets, and introduced new environment that favors the growth of food spoilage and food-borne pathogenic bacteria like Listeria monocytogenes (Gombas et al., 2003). Global food market now introduces novel foods and ready to serve, minimal processed or fresh cut foods. Hence these foods may need a longer and more complicate food chain which increase the chances of microbial contamination. So, there is always a gap for continuous innovative food preservation techniques that fulfill the demand from "farm to fork". Recently special courtesy has been given to bioprotection/biopreservation of food products to enhance the hygienic quality and shelf-life of food products. Biopreservation also improves the sensory and nutritional characteristics of fresh cut vegetable products. Bioprotection/biopreservation with use of naturally existing microorganisms and their metabolic products has an excellent history of benign use with high antimicrobial potential.

Bacteriocins are produced proteins or peptides having greater antibacterial potential towards closely related strains. Many of the bacteriocins have relatively high molecular weight $(>80$ $\mathrm{kDa}$ ) which destroy food spoilage and food pathogenic bacteria (Cascales et al., 2007). Recently, small, heat-stable cationic peptides produced from Gram positive bacteria are defined as bacteriocin, which have a broad antimicrobial inhibition spectrum (Cotter et al., 2005).

Many LAB bacteriocins have excellent antibacterial spectrum for food spoilage and food-borne Grampositive bacteria. External membrane protects the Gram-negative bacteria intrinsically. Nevertheless, recent techniques applied in freshcut vegetable processing manufacturers have enhanced shelf 
life and maximum quality of the products but food safety is still a matter of worry (Devlieghere et al., 2004; Cleveland et al., 2001).

A fascinating way to enhance microbiological food safety of fresh-cut vegetables is the application of natural microorganisms and their metabolic antibacterial peptides as a food biopreservative approach. The application of microorganisms such as LAB and their antimicrobial metabolites, has been recommended to improve the quality of fresh-cut vegetables (Leverentz et al., 2006). LAB forms several antibacterial products, among which bacteriocins are of special attention. Bacteriocins are regarded as natural and safe biopreservatives, because they are tarnished by enzyme proteases for the gastrointestinal tract and can be helpful for controlling food spoilage and food-borne pathogens as a primary hurdle (Cleveland et al., 2001). Nisin is a commercially available and widely studied bacteriocin. But, other bacteriocins such as lacticin, plantaricin and pediocins have greater applications in food environments (Deegan et al., 2006). Previous studies have shown that use of bacteriocins in combination may be more effective approach towards natural food biopreservation (Limonet et al., 2004; Bari et al., 2005).

The present study is designed to produce bacteriocin by bacteriocinogenic LAB strain isolated from indigenous dairy sources. The ability of bacteriocin to inhibit food-borne pathogens will be assessed. Moreover, the antimicrobial potential of bacteriocins as biopreservativesin fresh-cut vegetables will be evaluated. Keeping in view all the benefits of bacteriocins to be used as biopreservative, the present study has been designed forisolation and characterization of bacteriocinogenic LAB strains from indigenous dairy sources as well as production and characterization of bacteriocin from indigenous $\mathrm{LAB}$ strains.

\section{MATERIALS AND METHODS}

Isolation and identification of bacteria: Indigenous dairy (sour cream and cheese) samples were collected from local market of Faisalabad. The samples were kept under refrigerator temperature at $4^{\circ} \mathrm{C}$ in sterile sample holders and used to isolate the Lactococcus spp.10-1 $-10^{-6}$ dilutions of 1 gram of sample (sour cream) were made. Sample dilutions were plated on medium MRS agar to isolate the Lactococci strains. The strains were subcultured onto MRS agar medium and incubated for 24 hours at $30 \mathrm{C}$ then preserved in solution of $20 \%$ glycerol. One of the isolate (L. lactis) was taken for future studies which showed excellent antimicrobial potential against target organisms. The LAB isolate was identified and characterized on the basis of cell morphology,growth, gram staining and catalase activity, sugar fermentation profile and other basic physiological and biochemical tests.

Production of crude bacteriocin: After biochemical tests were confirm bacterial colony, then that colony culture was inoculated into MRS broth and incubate it for $48 \mathrm{hrs}$. Centrifugation was performed at $10,000 \mathrm{rpm}$ for $15 \mathrm{~min}$. at 4C and then cells were separated from the growth medium. The cell-free supernatant was used as crude bacteriocin and maintained at $\mathrm{pH} 6.0$ using $1 \mathrm{~N} \mathrm{NaOH}$.

Purification of bacteriocin: It was performed with 60 and $80 \%$ of the ammonium sulphate precipitation, stirred at room temp. The precipitate was resuspended with $20 \mathrm{mM}$ buffer as potassium phosphate at $\mathrm{pH} 6.0$ and temperature $5^{\circ} \mathrm{C}$. Membrane dialysis and ion exchange and gel filtered chromatography method was used for complete purification of isolate. The protein was precipitated and these precipitations contain our desired.20kDa dialysis membrane was used for the purpose of dialysis. The enzyme specific activity units were measured by Gelatin Digestion Unit (GDU) Assay. 1 GDU is defined asthe amount of enzyme, liberated one milligram of amino nitrogen from a standard gelatin solution at $\mathrm{pH} 5.5$ or $\mathrm{pH} 4.5$ at $45^{\circ} \mathrm{C}$ after $20 \mathrm{~min}$ of digestion.

SDS-PAGE for the measurement of molecular weight of bacteriocin:15\% sodium dodecyl sulfate polyacrylamide gel electrophoresis was used for the determination of molecular weight of bacteriocin from LAB isolate.

Antibacterial effect of bacteriocin: Agar well diffusion method was used for the antimicrobial potential of the bacteriocin from Lactococcus lactis. The supernatant culture 48 hours after incubation of Lactocccus lactis was filtered through $045 \mathrm{~mm}$ membrane filter, the sterile supernatant was put in $4 \mathrm{~mm}$ diameter wells that had been cut in MuellerHinton agar with the target organism. After 12 to 18 hours of incubation, it showed the diameters of the zones of growth inhibition.

\section{RESULTS AND DISCUSSION}

Isolation and identification of bacterial strain: The bacteriocin producing $\mathrm{LAB}$ strain was isolated from indigenous dairy source and the selected strain was identified as L. lactis subsp. lactis based on its biochemical and physiological properties as cell shapes comprised cocci, rods and tetrad-forming cocci. All isolates were Gram-positive, catalase-negative, non-spore formers capable of growth under anaerobic conditions. These are characteristics of lactic acid bacteria (Axelsson, 2004).(Table 1, Fig. 1). Figure 4 shows the biomass and bacteriocin production. LAB strain $L$. lactis produced a bacteriocin in MRS broth as shown in Figure 4 . The stationary phase was the best in production of bacteriocin, whereas biomass production was maximum at 20 hours. Moreno et al. (1999) have isolated the different strains of LAB from different food products like milk and cheese. The antimicrobial potential was measured through agar well diffusion method on agar plates (Toro, 2005). To avoid antagonism hydrogen peroxide also used for inhibiting antagonism with catalase by adding to the culture medium; 
phosphate was added to the solid medium as buffer to avoid inhibition with the use oforganic acids. LAB are used in the production of foods prepared by lactic fermentation such as dairy products, fermented vegetables, fermented meats, and sourdough bread (Moulay et al., 2013). LAB have a wide range of antimicrobial activities, among these activities, the production of lactic acid and acetic acid is obviously the most important. On the other hand, certain strains of LAB are known to produce bioactive molecules like ethanol, formic acid, fatty acids, hydrogen peroxide, diacetyl, reuterin, and reutericyclin. Many strains also produce bacteriocins and bacteriocin-like molecules that display antibacterial activity (Aween et al., 2012).

Table 1. Biochemical characteristics of $L$. lactis.

\begin{tabular}{ll}
\hline Biochemical test & Lactococcu lactis \\
\hline Growth in & Uniform \\
Gram staining & Gram positve \\
Catalase test & Negative \\
Indole & Negative \\
Methyl red & + \\
Voges & - \\
Carbohydrate fermentation & + \\
\hline
\end{tabular}

Table 2. Sugar fermentation profile.

\begin{tabular}{|c|c|c|c|c|c|c|c|c|c|c|c|}
\hline $\mathscr{\sim}$ & $\frac{\overline{0}}{\stackrel{0}{8}}$ & $\frac{x}{\Delta}$ & 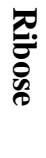 & 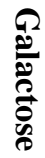 & 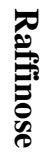 & 交 & 象 & 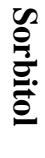 & 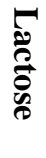 & 光 & $\frac{\Omega}{\tilde{\Xi}}$ \\
\hline 1 & $\mathrm{LC}_{1}$ & - & + & + & - & + & - & + & + & + & + \\
\hline 2 & $\mathrm{LC}_{2}$ & - & + & + & - & + & - & - & + & + & + \\
\hline 3 & $\mathrm{LC}_{3}$ & - & + & + & - & + & + & - & + & + & + \\
\hline 4 & $\mathrm{LC}_{4}$ & - & + & + & - & + & - & - & + & + & + \\
\hline 5 & $\mathrm{LC}_{5}$ & - & + & + & - & + & - & - & + & + & + \\
\hline
\end{tabular}

LC $=$ Lactococcus lactis subsp. lactis

In general, LAB used in fermentation of milk products are proteolytic due to the instability of milk proteins. The proteolytic system of LAB is important for growth of microorganisms and in native free amino acid of milk. Proteolytic system is involved in casein utilization within LAB cell contributing to development of organoleptic properties of fermented milk products (Yamina et al., 2013). The identification of lactic acid bacteria was established many years ago because of the need to determine the strains that can be used in the industry to characterize the properties and the marketing value of the strain, and above of that is to confirm the safety of the strain to be used in the food application or even in pharmaceutical application. Historically, the identification of LAB was based on phenotypic and chemical methods. These methods depend on the activity of the LAB, carbohydrates fermentation, gas production, motility and spore production (Ashmaig et al., 2009).

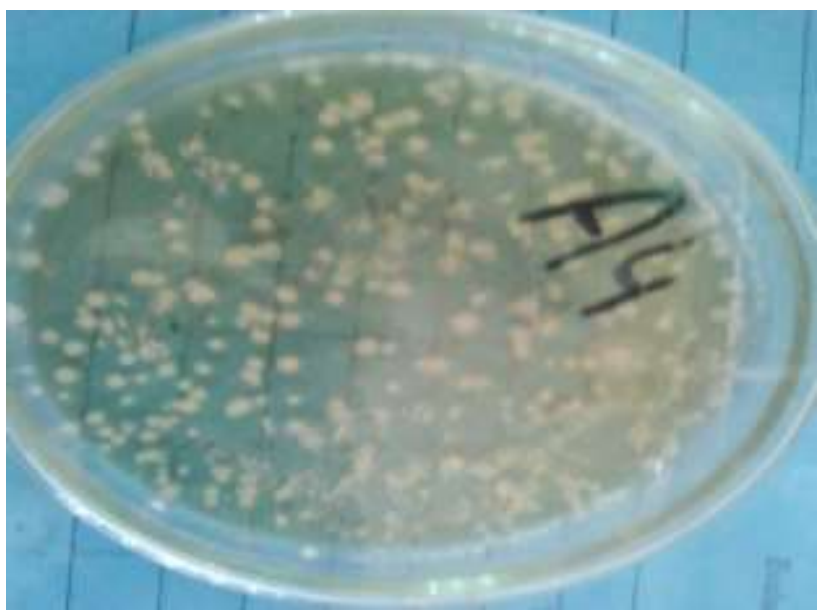

Figure 1. Lactic acid bacterial colonies (LAB)/ Growth of Lab.

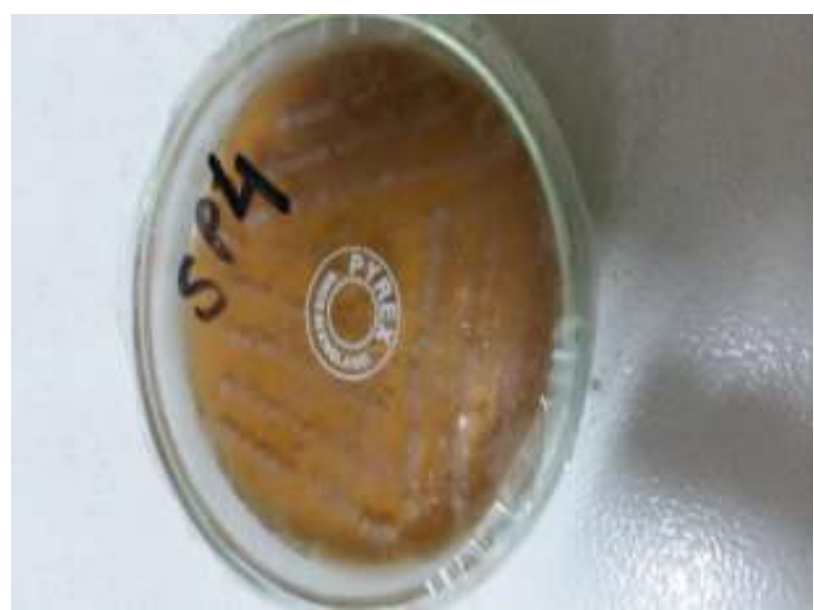

Figure 2. Streak plates of LAB isolates for purification.

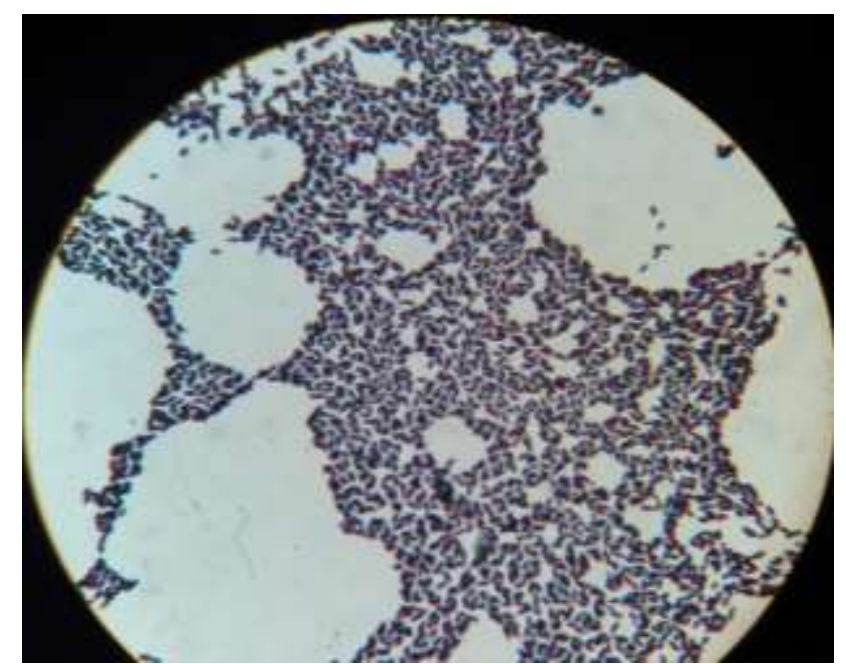

Figure 3. Gram's stained slide of isolated LAB strain ( $L$. lactis). 
Table 3. Purification of bacteriocin (lacticin SC07).

\begin{tabular}{lccccc}
\hline Sample & $\begin{array}{c}\text { Total activity } \\
(\mathbf{u})\end{array}$ & $\begin{array}{c}\text { Total protein } \\
(\mathbf{m g} / \mathbf{m l})\end{array}$ & $\begin{array}{c}\text { Specific activity } \\
\mathbf{U} / \mathbf{m g}\end{array}$ & $\begin{array}{c}\text { Recovery fold } \\
\text { Crude }\end{array}$ & $\begin{array}{c}\text { Fold purification } \\
\text { based on activity }\end{array}$ \\
60\% Saturation & $10.2 \times 10^{3}$ & 17.56 & $55 \times 10^{1}$ & 1 & 1 \\
$80 \%$ Saturation & $26 \times 10^{5}$ & 12 & $58 \times 10^{3}$ & 1.7 & 106 \\
Dialysis & $28 \times 10^{5}$ & 8 & $218 \times 10^{4}$ & 437 & 3972 \\
IEC Extract & $34 \times 10^{5}$ & 6 & $345 \times 10^{5}$ & 460 & 62740 \\
Gel filtered Extract & $58 \times 10^{5}$ & 1.8 & $573 \times 10^{5}$ & 573 & 104176 \\
\hline
\end{tabular}

Bacteriocin production and harvesting of biomass: Harvesting of biomass and production of bacteriocin is shown in Fig. 4. Figure 4 showed the biomass and bacteriocin production. LAB strain $L$. lactis produced a bacteriocin in MRS broth. The LAB strain L. lactis showed excellent bacteriocin potential at $\mathrm{NaCl} 1.5 \%, \mathrm{pH} 6.0$ and at $30^{\circ} \mathrm{C}$ as $2294 \mathrm{AU} / \mathrm{ml}$. The stationary phase was the best in production of bacteriocin, whereas biomass production was maximum at $20 \mathrm{~h}$.

A study was conducted and reported the optimal bacteriocin production during late log phase and early stationary phase of the culture. This might be because of partial degradation and/or adsorption on producer cells. Highest bacteriocin titers were always been obtained after eight hours of incubation at $35^{\circ} \mathrm{C}$. But current findings suggest highest titer was obtained after 20 hours of incubation during the early stationary phase. It has been well cited in literature that bacteriocin is produced during late exponential and early stationary growth phase. Various authors have reported the decrease in bacteriocin activity after $48 \mathrm{~h}$ of incubation. The researchers found that production of crispacin A in MRS broth was dependent on phase of bacterial growth. Callewaert et al., (2013) described that bacteriocin production starts early in growth cycle and continues till the beginning of the stationary phase. During the stationary phase bacteriocin producing cells are killed. The inhibition of adsorption of the bacteriocin molecules to the cell surface by ethanol can prevent subsequent cell death due to a limited immunity of bacteriocin producer cells. According to Parante and Ricciardi (2005), bacteriocin production rate improves in continuous fermentations where high growth rates can be maintained. Cherif et al., (2001) recovered inhibitory activity of culture supernatant at mid logarithmic phase and during stationary phase. Maximum bacteriocin production in L. acidophilus DSM20079 was obtained at the end of exponential growth phase (Deraz et al., 2007). Bacteriocin showed maximum production during late $\log$ phase and early stationary phase after 20 hours of incubation as $5800 \mathrm{AU} / \mathrm{ml}$ and $6000 \mathrm{AU} / \mathrm{ml}$ after 24 hours of incubation as shown in figure 6. Similar trends have been reported in other bacteriocin production studies (Ghrairi et al., 2008; Huang et al., 2009; Todorov and Dicks, 2009).

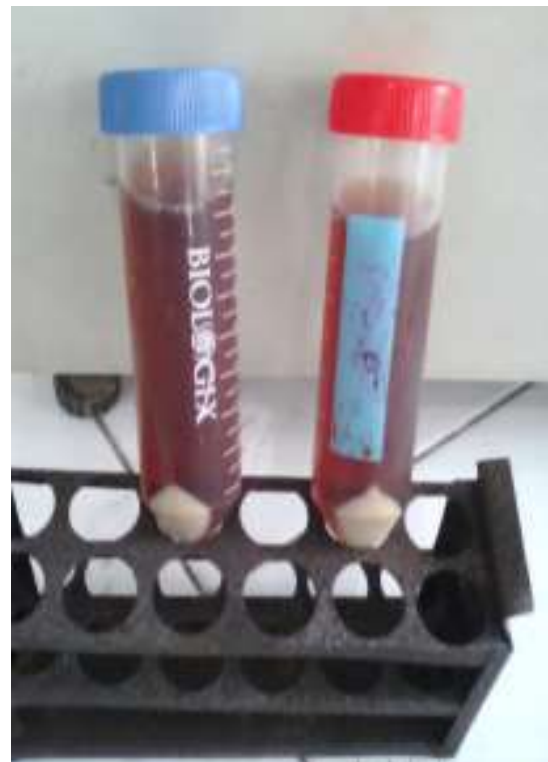

Figure 4. Lyophilized isolated bacterial mass after centrifugation. Figure clearly showed the bacterial biomass and crude bacteriocin production.

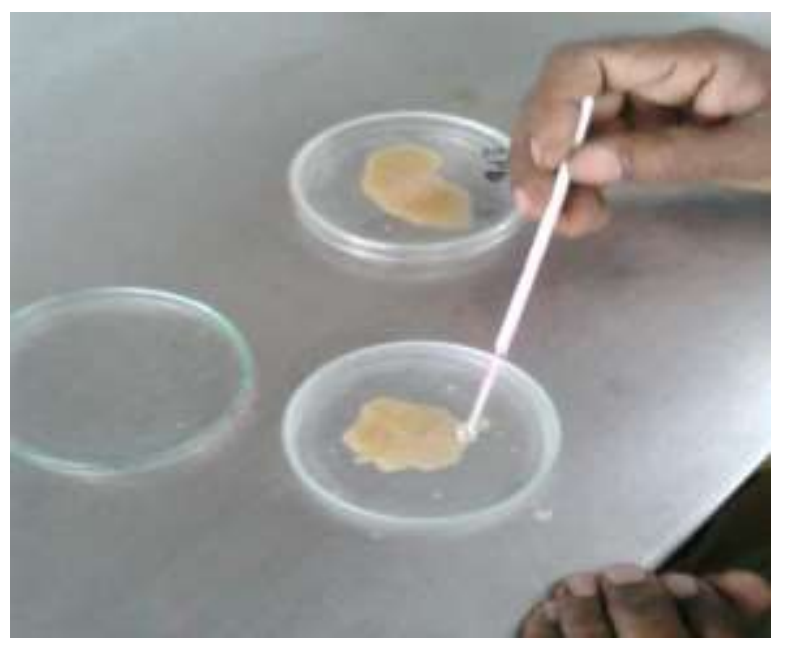

Figure 5. Freeze dried isolated bacterial biomass which was aseptically packed in polythene bags for further studies. 


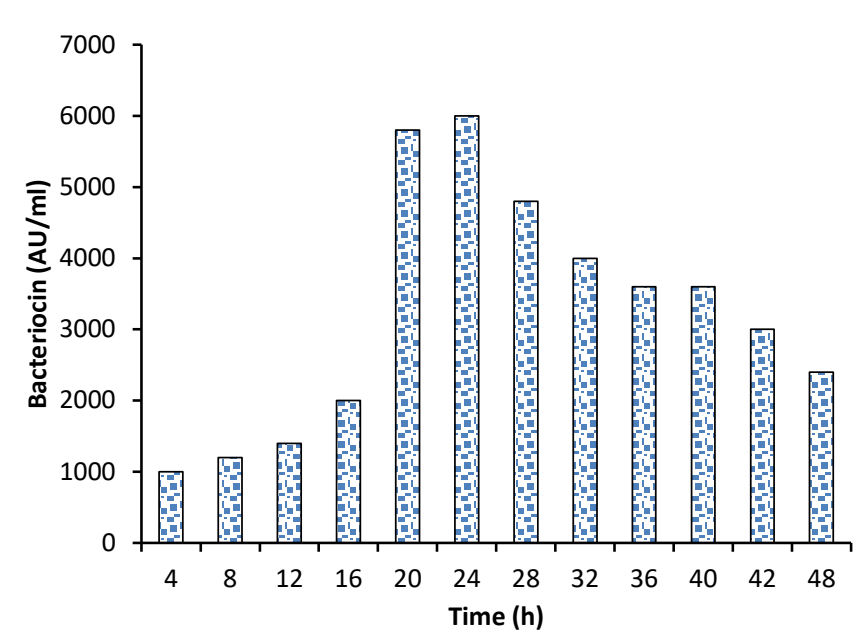

Figure 6. Bacteriocin production at $600 \mathrm{~nm}$ OD in different time intervals.

Purification of bacteriocin: The recoveries and purification steps of bacteriocin production are shown in Table 2. At $60 \% \mathrm{~V}$ ammonium sulfate saturation, a 1.7 -fold increase in total activity of bacteriocin was recovered in pellet. Upon subsequent treatment with ammonium sulfate at $80 \%$ saturation activity in the resulting pellet measured 437 -fold higher than that in the initial active supernatant. Desalting of the active extract gave the indistinguishable bacteriocin titer. Thus, a significant increase in specific activity occurred during this step of purification. Taking into account the increase in total activity, the specific activity rose by a factor 3972. However, on the basis of proteins levels it appeared that bacteriocin (lacticinSC07) had been purified 102-fold. Centrifugation was used for the filtrate culture purification, and $80 \%$ ammonium sulphate precipitation and dialysis methods used for the protein concentration. Cold environment was maintained in a room for all the procedures. Bacteriocin was purified from culture supernatant extracellularly $>12$. The specific-activity was found markedly increased after ammonium sulphate precipitation (Alam et al., 2011). Other researchers also used $80 \%$ Ammonium sulphate saturation to precipitate bacteriocins from $B$. thuringiensis subsp. entomocidus, B. cereus and B. subtilis LFB112 (Cherif et al., 2008; Risoen et al., 2004; Xie et al., 2009) respectively. The antimicrobial substance produced by $B$. amyloliquefaciensMBL27 was precipitated readily by adding $40 \%$ saturation with about $98 \%$ recovery of the antimicrobial protein. Ammonium sulphate fractionation was used as the first step in purification protocol for B. thuringiensis (Ahern et al., 2003). The maximum yield and antimicrobial activities are summarized in Table 2.

Molecular weight determination in SDS-PAGE: SDSPAGE gel electrophoresis used for determination of molecular weight of bacteriocin as shown in Figure3. This bacteriocin was stained with Comassie blue and it showed single protein band which is the clear evidence of protein purity. The calculated molecular weight of the bacteriocin which was purified was about $3.7 \mathrm{kDa}$. To confirm the identity of 1.7-kDa band fractions derived from the $\mathrm{Bac}^{-} \mathrm{Bac}^{+} L$. lactis subsp. lactis which were analogous to lacticin SC07. Eluting fractions were recovered and analyzed by SDS-PAGE. No 1.7-kDa band or activity was detected (Fig. 2, lane 4) confirming that the 1.7-kDa purified band from Lactococcus lactis subsp. lactis was lacticin SC07. So far, various bacteriocins isolated from $\mathrm{LAB}$ in meat and dairy products have been reported. These bacteriocins are as follows: acidocin D20079 (6.6 kDa) produced by L. acidophilus DSM 20079 (Deraz et al., 2005), bacteriocin KCA2386 (8.1 kDa) produced by Lactococcus lactis (Ko and Ahn, 2000), plantaricin $35 \mathrm{~d}(4.5 \mathrm{kDa})$ produced by L. plantarum $35 \mathrm{~d}$ (Messi et al., 2001), bacteriocin ST44AM (6.5 kDa) from Pediococcus pentosaceus ST44AM (Todorovand Dicks 2009), bacteriocin AMA-K (2.9 $\mathrm{kDa})$ from $L$. plantarum AMA-K, bacteriocin ST414BZ (3.7 kDa) from L. plantarum ST414BZ (Todorov and Dicks, 2010), sakacin C2 (5.5 kDa) from L. sakei $\mathrm{C} 2$ (Gao et al. 2010). The molecular weights generally range from $3 \mathrm{kDa}$ to $10 \mathrm{kDa}$. Bacteriocins with the molecular weights higher than $10 \mathrm{kDa}$ are not common. In this paper, the molecular weight of bacteriocin lacticin $\mathrm{SC} 07$ was $3.7 \mathrm{kDa}$.

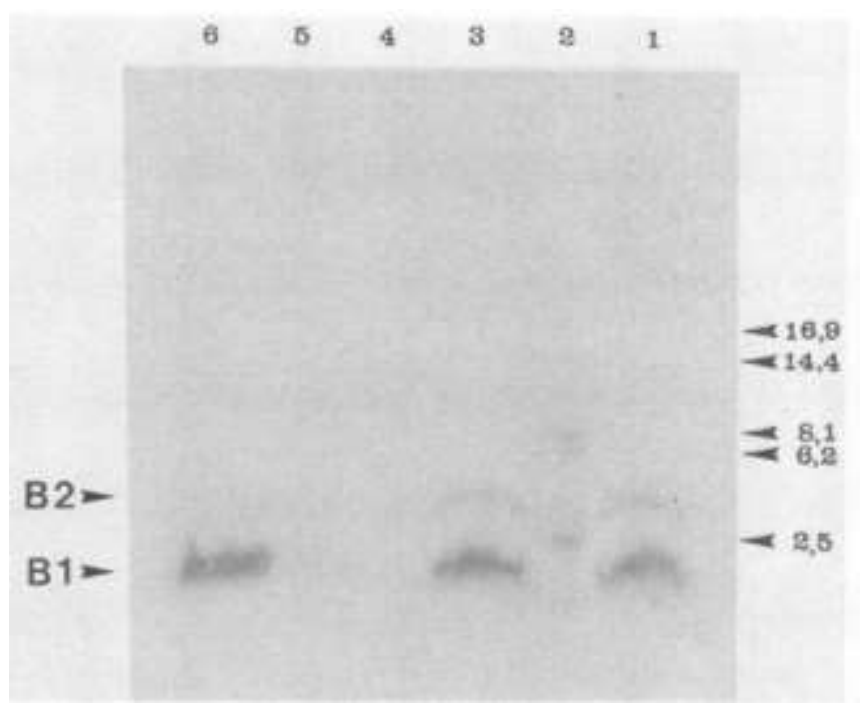

Figure 6. Coomassie blue-stained bacteriocin containing protein bands from a Sodium Dodecyl SulfatePAGE for the determination of molecular weight of bacteriocin. Lanes: 1 and 3 . Ammonium sulfate saturated and IEC aliquots respectively: 4 . The gel filtered extract from $L$. lactis subsp. lactis: 5 dialysis aliquot: 6 molecular weight standards. Two protein bands are visible on the membrane: $\mathrm{B} 1$ is a $1.7-\mathrm{kDa}$ peptide and $\mathrm{B} 2$ is a 3.7-kDa peptide. 
Antibacterial potential of bacteriocin: L. monocytogens susceptibilities with culture supernatant to growth of L. lactis are presented in Figure 7. LAB is well known to produce different low molecular weight antimicrobial substances which may prevent other bacterial growth. The antimicrobial potential might be because of the organic acids especially lactic acid and acetic acids, bacteriocins, hydrogen peroxide, ethanol, carbon dioxide, and diacetyl which were produced during fermentation processes (Elyass, 2010). The agar well diffusion method was found better option to examine the antibacterial potential of LAB bacteriocins which were studied against 6 communal plant/food spoilage organisms and bacterial pathogens at 5 and $20^{\circ} \mathrm{C}$ (Sharpe, 2009; Yang, 2011).

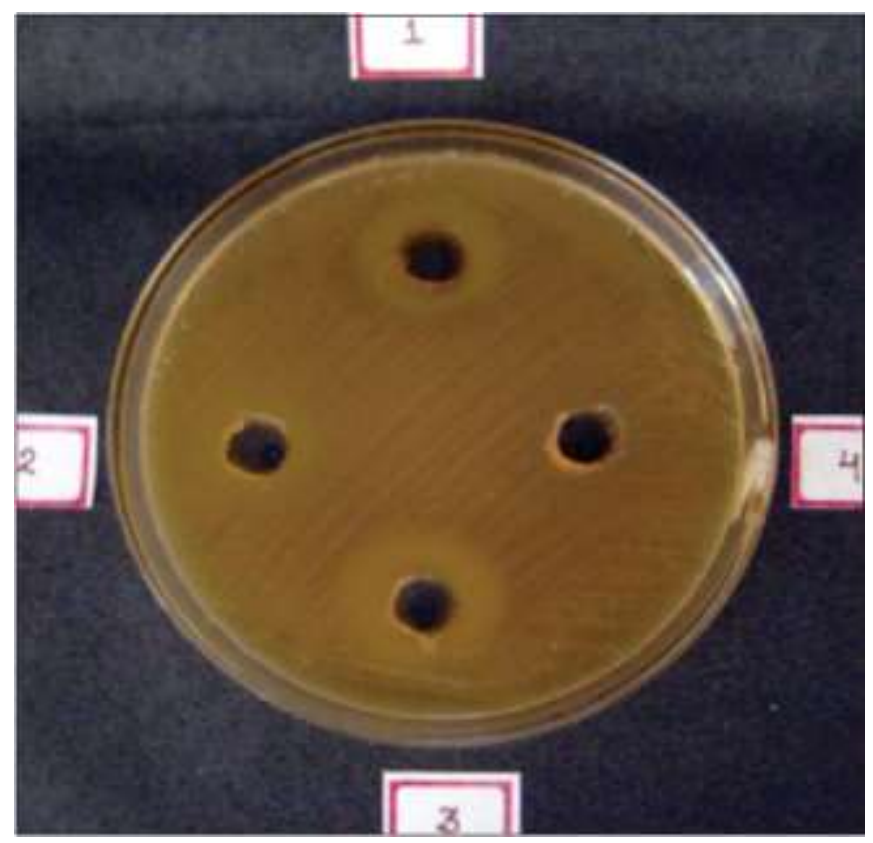

Figure 7. Antimicrobial potential of crude bacteriocin solution against $L$. monocytogen.

Conclusion: This research effort has demonstrated the isolation and characterization of bacteriocinogenic lactic acid bacteria and production of bacteriocins. LAB bacteriocin (lacticin) showed excellent antimicrobial potential during the present research work. One of the prime application of this property is the utilization of bacteriocinogenic strains of LAB as biopreservative in minimally processing industries of vegetables. This will help to improve the microbiological quality of the product through controlling the growth of other, unwanted, microorganisms. In the end, the acceptance and use of purified bacteriocins in food preservation as safe and natural additives is expected to expand rapidly. It is, therefore, recommended that further probing and exploration of bacteriocionogenic strains of bacteria, particularly $\mathrm{LAB}$, should be undertaken. It is hoped that the presently flourishing local food industry should back such efforts, as well as seek ways of making practical use of research findings in this field. This will certainly be more than welcome in view of the increasing demand by consumers for more "natural" food preservation methods.

\section{REFERENCES}

Ahern, M., S. Verschueren and D. van Sinderen. 2003. Isolation and characterisation of a novel bacteriocin produced by Bacillus thuringiensis strain B439. FEMS Microbiol. Lett. 220:127-131.

Alam, S.I. M. Kamran, M. Sohail, A. Ahmed andS.A. Khan. 2011. Partial characterization of bacteriocine like inhibitory substance. Pak. J. Bot. 43:2195-2199

Ashmaig, A., A. Hasan and E.E. Gaali. 2009. Identification of Lactic Acid Bacteria IsolatedFrom Traditional Sudanese Fermented Camel's Milk (Gariss). African J. Microbiol. Res.3: 451-457.

Aween, M., Z. Hassan and M. Belal. 2012. Evaluation on Antibacterial Activity of Lactobacillus acidophilus Strains Isolated from Honey. American J. Appl. Sci. 9:807-817.

Axelsson, L.2004. Lactic Acid Bacteria: Classification and Physiology. In: S. Salminen, A. vonWright and A. Ouwehand (eds.), Lactic Acid Bacteria: Microbial and Functional Aspects, $3^{\text {rd }}$ Ed. Marcel Dekker, New York. pp.1-66.

Bari, M.L., D.O. Ukuku, T. Kawasaki, Y. Inatsu, K. Isshiki and S. Kawamoto. 2005. Combined efficacy of nisin and pediocin with sodium lactate, citric acid, phytic acid, potassiumsorbate and EDTA in reducing the Listeria monocytogenes population of inoculatedfresh-cut produce. J. Food Prot. 68:381-1387.

Callewaert,C.,K. Frederiek-Maarten ， S.Michael,M. Granitsiotis, T. Van Gele,,B. Nico . 2013. Characterization of Staphylococcus and Corynebacterium Clusters in the Human Axillary Region. Plos one. 8:2-6.

Cascales, E., S.K. Buchanan, D. Duche, C. Kleanthous, R. Lloubes, K. Postle, M. Riley, S.Slatin and D. Cavard. 2007. Colicin biology. Microbiol. Molecul.Biol. Rev. 71:158-229.

Cherif, A., H. Ouzari, D. Daffonchio, H. Cherif, K. Ben Slama, A. Hassen, S. Jaoua and A.Boudabous. 2001. Thuricin 7: anovel bacteriocin produced byBacillus thuringiensisBMG1.7, a new strain isolated from soil.Appl. Microbiol. 32:243-247.

Cherif, A., W. Rezgui, N. Raddadi, D. Daffonchio and A.Boudabous. 2008. Characterizati onand partial purification of entomocin110, a newly identified bacteriocin from Bacillusthuringiensis subsp. entomocidus HD110. Microbiol. Res.163:684-692. 
Cleveland, J., T.J. Montville, I.F. Nes and M.L. Chikindas. 2001. Bacteriocins: Ssafe, natural antimicrobials for food preservation. Int. J. Food Microbiol. 71:1-20.

Cotter, P.D., C. Hill and R.P. Ross. 2005. Bacteriocins: developing innate immunity for food.Nat. Rev. Microbiol. 3:777-788.

Cotter, P.D., C. Hill and R.P. Ross. 2005. Bacteriocins: developing innate immunity for food. Nat. Rev. Microbiol. 3:777-788.

Deegan, L.H., P.D. Cotter, C. Hill and P. Ross. 2006. Bacteriocins: biological tools for bio-preservation and shelf-life extension. Int. Dairy J. 16:1058-1071.

Deegan, L.H., P.D. Cotter, C. Hill and P. Ross. 2006. Bacteriocins: biological tools for bio-preservation and shelf-life extension. Int. Dairy J. 16:1058-1071.

Deraz S.F., E.N. Karlsson, M. Hedström, M.M. Andersson, B. Mattiasson. 2005: Purification and characterisation of acidocin D20079, a bacteriocin produced by Lactobacillus acidophilus DSM 20079. J. Biotech.117:343-354.

Deraz, S., N.E. Karlsson, A.A. Khalil and B Mattiasson. 2007. Mode of action of acidocin D20079, a bacteriocin produced by the potential probioticstrain, Lactobacillus acidophilus DSM 20079. J. Ind. Microbiol. Biotechnol. 34:373-379.

Drider, D., G. Fimland, Y. Hechard, L.M. McMullen and H. Prevost. 2006. The continuing storyof class IIa bacteriocins. Microbiol. Mol. Biol. Rev. 70:564-582.

Elyass, M.E. 2010. Identification of some bacteriocinogenic lactic acid bacteria and characterization of their bacteriocins. M.SC. Thesis Sudan University for Science and Technology.

European Ffood Ssafety Aauthority (EFSA). 2009. Advice on the EFSA guidance document for the safety assessment of botanicals and botanical preparations intended for use as food supplements, based on real case studies. Aavailable online http://www.efsa.europa.eu/EFSA/efsa_locale1178620753812 _ 496.

Galvez, A., H. Abriouel, R.L. Lopez and N.B. Omar. 2007. Bacteriocin-based strategies for foodbiopreservation. Int. J. Food Microbiol. 120:51-70.

Gao Y., S. Jia and Q. Gao. 2010. A novel bacteriocin with a broad inhibitory spectrumproduced by Lactobacillus sake $\mathrm{C} 2$, isolated from traditional Chinese fermented cabbage.F. Control. 21:76-81.

Ghrairi, T., J. Frere, J.M. Berjaud and .M Manai. 2008. Purification and characterization ofbacteriocins produced by Enterococcus faecium from Tunisian rigouta cheese. F.Control. 19:162 -169.

Gombas, D.E., Y. Chen, R.S. Clavero and V.N. Scotta. 2003. Survey ready to-eat foods. J. FoodProt. 66:559-569.

Huang,W.,B. T. Sherman andR. A. Lempick. 2008. Systematic and integrative analysis of large gene lists using DAVID bioinformatics resources. Nature Protocols.4:44 - 57.

Joerger, M.C. and T. R. Klaenhammer. 1986. Characterization and purification of helveticin Jand evidence for a choromosomally determined bacteriocin produced by Lactobacillushelveticus 481. J. Bacteriol. 167:439-446.

Ko S.H. and C. Ahn. 2000. Bacteriocin production by Lactococcus lactis KCA2386 isolatedfrom white kimachi. F. Sci. Biotech. 9:263-269.

Leverentz, B., W.S. Conway, M.J. Camp, W.J. Janisiewicz, T. Abuladze, M. Yang, R. Saftnerand A.Sulakvelidze.2003.Biocontrol of Listeria monocytogenes on fresh-cutproduce by treatment with lytic bacteriophages and a bacteriocin. Appl. Environ. Microbiol. 69:4519-4526.

Limonet, M., A. evol-Junelles, C. Cailliez-Grimal and J. Milliere. 2004. Synergistic mode of action of mesenterocins 52A and 52B produced by Leuconstocmesenteroides subsp. mesenteroides FR 52. Curr.Microbiol. 48:204-207.

Messi P., M. Bondi and C. Sabia. 2001. Detection and preliminary characterization of abacteriocin (plantaricin 35d) produced by a Lactobacillus plantarum strain. Int. J. F. Microbiol. 64:193-198.

Moreno, I., A.S.L. Lerayer and M.F.F. Leitao., 1999. Detection and characterization ofbacteriocinproducing Lactococcus lactis strains. Rev. Microbiol. 30:130-136.

Moreno, M.R., P. Sarantinopoulos, E. Tsakalidou and L. De Vuyst. 2006. The role andapplication of enterococci in food and health. Int. J. Food Microbiol. 106:1-24.

Moulay, M., K. Benlancen, H. Aggad and M. Kihal. 2013. Diversity and Technology Propertiesof Predomonant Lactic Acid Bacteria Isolated From Algerian Raw Goat Milk. Adv. Env.Biol.7:999-1007.

Parada J.L.,C.R.Caron, A.B.P. Medeiros and C.R. Soccol. 2007. Bacteriocins from LacticAcid Bacteria: Purification, Properties and use as Biopreservatives. Braz.ilian Arch. ofBiol. and Technol. 50:521-542.

Ricciardi, A., R.G. Ianniello, A. Tramutola, E. Parente and T. Zotta. 2014. Rapid detection assay for oxygen consumption in the Lactobacillus casei group. Ann. Microbiol. 64:1861-1864.

Risoen, P.A., P. Ronning, I.K. Hegna and A.B. Kolsto. 2004. Characterization of a broad rangeantimicrobial substance from Bacillus cereus. J. App. Microbiol. 96:648-655.

Sharpe, D.V. 2009. Biopreservation of fresh-cut salads using bacteriocinogenic lactic acidbacteria isolated from commercial produce. M.Sc. Thesis AAFC, NS and DalhousieUniversity, Halifax Canada.

Todorov S.D. and L.M.T. Dicks. 2009: Bacteriocin production by Pediococcus pentosaceusisolated from marula. Int. J. F. Microbiol.132:117-126. 
Toro, C.R. 2005. Uso de bactérias láticas probióticas na alimentação de camarões Litopenaeus vannamei Como inibidoras de microrganismos patogênicos e estimulantes do Sistema imune. PhD Thesies, Universidade Federal do Paraná, Curitiba, Brazil.

Xie, J., R. Zhang, C. Shang and Y. Guo. 2009. Isolation and characterization of a bacteriocin produced by an isolated Bacillus subtilisLFB112 that exhibits antimicrobial activity against domestic animal pathogens. African J. Biotechnol. 8:5611-5619.
Yamina, M., C. Wassila, Z. Kenza, Z. Amina, S. Noureddein, H. Eddine, \& K. Mebrouk. 2013.Physico Chemical and Microbiological Analysis of Algerian Raw Camels Milk and Identification of Properties of Predominating thermoophilic Lactic Acid Bacteria. J. F.Sci.Engi. 3:5563.

Yang, E. 2011. Botanical Garden. Ph.D Thesis,. Collected in the AAFC, Nova Scotia, Canada. South China Chinese Academy of Sciences, Guangzhou, China. 